UDK 613.164:711.4]:630*27(497.6 Sarajevo)

\title{
COMMUNAL NOISE AND THE EFFECT OF CITY GREENERY ON THE LEVELS OF COMMUNAL NOISE IN SARAJEVO
}

\author{
Komunalna buka i uticaj gradskog zelenila na njen nivo u Sarajevu
}

\author{
Jusuf Musić $^{1}$, Adela Muhić ${ }^{2}$, Safet Gurda ${ }^{1}$, Mirza Dautbašić ${ }^{1}$
}

\begin{abstract}
Noise represents any unwanted, too loud, unpleasant or unexpected sound which negatively affects physical and/or mental health of people. Noise impedes human activities, causes indisposition, irritability, unrest, mental health and behaviour issues, fatigue and sleep deprivation, and even aggressive behaviour with noise volumes above $80 \mathrm{~dB}$. In urban areas, i.e. all the places man lives and works in, the noise people are exposed to daily is called environmental, communal or general noise. Communal noise is a major problem of the closer human environment, especially in urban areas. One reliable means of protection against communal noise is an array of different green plantations. They absorb sound waves and thus lower the level of noise. The larger the density and depth of the plantations, the higher the level of noise protection, and the effectiveness also depends on the character of the plantations (composition, layout of different plants, construction, density, the presence of undergrowth and the shrub layer, height, etc.).

In relation to the abovementioned, measuring communal noise in two distinctive locations in Sarajevo was conducted within this paper. The main objective of these measurings is to ascertain, in relation to allowable values (Law on noise protection in Sarajevo Canton), whether and to which degree communal noise exceeds the legally prescribed levels. Apart from that, the framework of this paper strives to ascertain the level to which city greenery affects lowering noise levels.

The results show that the measured noise levels in both localities exceed the allowable values regulated by law to a great extent. It is also ascertained that city greenery lowers the noise level by approximately $8 \%$,thus the paper presents recommendations on the method of erecting city greenery for purposes of noise protection.
\end{abstract}

Key words: communal noise, city greenery

\footnotetext{
${ }^{1}$ Faculty of Forestry Univerity of Sarajevo

${ }^{2}$ BSc. Horticulture
} 


\section{INTRODUCTION - Uvod}

The urbanisation process of the area man used to live in started as a complex result of the growing number of people and their concentration, production, trade and craft development. It started with the growth of civilisation and the creation of towns, but it intensified to a great extent only after the Industrial Revolution. Together with urbanisation and the creation of the so-called metropolis and mega polis, we see the creation of their basic environmental issues: air pollution, drinking water shortage, waste material increase, excessive city noise, lack of green spaces, the estrangement of the human individual etc. In relation to the abovementioned basic problems and the need for overcoming them, city greenery is created, primarily for aesthetic purposes in the form of different gardens (Egypt, Greece, Rome), and later with an architectural (division and connection in space) and sanitary function (noise and dust protection). The greenery in today's city areas is of great environmental importance: replenishing oxygen in the air, lowering air pollution, regulating air temperature, increasing air humidity, lowering wind speed, lowering sun radiation, beneficial effect on human health and noise lowering.

Noise can be characterised as the so-called invisible 'pollutant' of planet Earth and is one of the most difficult issues to solve in the world today, despite different attempts to lower it. The noise in urban areas, that is all the places man works and lives in and to which one is exposed to, is called environmental, communal or general noise and it is one of the biggest issues of the immediate human environment. The single most important cause of communal noise is traffic. Other noise sources, industrial objects, indoor noise and street noise are of different origin and are present to a lower extent. Communal noise is difficult to systematize since it results from different sources and is of a changing character. Characteristic of this noise is that: (a) it is not determined by time, (b) it is not limited by space and (c) it acts more or less in continuity (VIDAKOVIĆ, 2012).

Noise can be defined as any unwanted, too loud, unpleasant and/or unexpected sound which can be dangerous for the health of people or can affect people in a negative way. Basic SI units are used to estimate noise: air pressure in the Pascal $(\mathrm{Pa})$, sound intensity in watt per square meter $\left(\mathrm{W} / \mathrm{m}^{2}\right)$ and frequency in hertz $(\mathrm{Hz})$. A great step forward in ascertaining the noise indicator proportional to the effects of noise on the human body was made by creating the so-called A -weighted sound pressure level (in $\mathrm{dB}(\mathrm{A})$ ) to account for the relative loudness perceived by the human ear. It is achieved by correctional filters in SLMs wherein the A-filter simulates the human ear by giving greater significance to the high frequency bands which are more damaging for people, and less significance to low frequency bands which are less damaging (GomzI, 2005).

Noise is a subjective notion determined by physical features of sound and the physiological properties of the ear and the human body. Communal noise affects the quality of life in a specific area to a great extent, and to a lesser extent it affects the 
damage of human organs. Environmental and recreational noise $\mathrm{L}_{\mathrm{eq}}=<70 \mathrm{~dB}(\mathrm{~A})$ does not cause hearing loss with most people (Gomzl, 2005). It mostly results in deconcentration and annoyance, and can also cause aggressive behaviour. It is the cause of derangement, early aging and in $30 \%$ cases it shortens the life expectancy of large city residents. Noise interferes with human activities, communication through speaking, studying, listening to radio or TV programmes, focusing, relaxing and sleeping. It causes indisposition, unrest, mental health and behaviour issues, fatigue and sleep deprivation. For a good sleep, it is desirable for noise levels not to go over $30 \mathrm{~dB}$, and single sound stimuli not to go over $45 \mathrm{~dB}$ (Gomzl, 2005).

Along with air pollution and water pollution, noise pollution results in different diseases. Non-auditory health disorders are an expression of a physiological reaction to stress. Most effects are short-lived and temporary: issues with the cardiovascular, digestive and immune system, attention and memory span loss, field of view constriction. These issues can become chronic ones: sleep deprivation, increased blood pressure, eating and sexual function disorder, anxiety and depression. Long-term traffic noise exposure $\mathrm{L}_{\text {aeq }}=65-70 \mathrm{~dB}$ can lead to serious health issues or aggravate the existing ones such as arthritis, bronchitis, depression (NIEMANN AND MASCHE, 2004). Continuous noise exposure disrupts appropriate human communication in a psychological aspect, and also has long-term effects which are manifested by a decreased frustration tolerance, an increased reaction threshold and even minimum noise causes the rise of anxiety, aggressive and hostile behaviour. These noise effects can also partially explain the contemporary fashion of dehumanising relationships (GREGUREK, 2005).

It is estimated that $40 \%$ people in Europe are exposed to traffic noise of air pressure level above $55 \mathrm{~dB}$ during the day, and $20 \%$ people are exposed to levels above $65 \mathrm{~dB}$. In the USA, approximately $30 \%$ working population is exposed to noise above $85 \mathrm{~dB}$, and $20 \%$ population above $90 \mathrm{~dB}$. These noise levels are considered inadmissible for long-term exposure of the general population. The Federal Department of Environmental Protection in Germany managed to calculate that two in one hundred heart attacks are directly connected to noise pollution, because the values above $55 \mathrm{~dB}$ double the risk of high blood pressure. Noise during sleep is the most harmful. (BoGADIŠARE, 2005).

Environmental noise is monitored by passing regulations, standards and measures which limit the number and intensity of the source; physically separate and remove the sources of noise and the people, and educate the population. European guidelines on environmental noise, which should also be a part of our regulations (Green Paper on Future Noise Policy, COM(96) 540, Directive EC 2002/49), state the need for establishing a network of noise experts, creating noise maps based on uniform indicators, informing the public about the exposure to noise and the effects on health, creating an action plan, coordinating the regulations on noise sources and technical documentation of devices as well as long-term financial support for noise research. The document 'Environment 2010: Our Future, Our Choice' (EuROPEAn Commission, 2001) 
states as its objective and task the decrease of the number of people affected by noise by $10 \%$ until 2010 , and additional $20 \%$ by 2020 . Some other European Union documents are more precise in stating the measures, such as passing laws and regulations, developing noise tracking systems alongside establishing strategic noise maps which encompass the main roads, cities and settlements, as well as a demand for every community to create their own plans of action for reducing noise. On the state level, it is required to formulate and pass 'National strategies for health protection related to noise'. The recent research, commissioned by the European Commission, estimates that the annual benefit of reducing traffic noise for EU-27 is going to be at least $€ 5.8$ billion per $\mathrm{dB}$ or close to $0.05 \%$ GDP per $\mathrm{dB}$. Therefore, noise is economically very significant and it should logically be a part of any ex-antelarge infrastructure evaluation projects (NIJLAND AND WEE, 2008).

The functions, values and benefits of city green surfaces are numerous and can be estimated both from the economical aspect as well as the aspect of the quality of life of the local population. One of the more important environmental benefits is lowering noise levels. The larger the density and depth of the plantations, the higher the level of noise protection. The efficiency of noise reduction also depends on the type of plantations, the layout of plants, construction, the presence of undergrowth and the shrub layer, height etc. (VUJKOVIĆ, 2003).

Apart from measurable parameters $(\mathrm{dB})$, the important role of trees is seen in the so-called 'white noise'i.e. the sound of leaves and branches in wind which alleviates the negative effects of artificial noise sources in a certain way (CODER, 1996).

\section{RESEARCH GOALS - Ciljevi istraživanja}

The main objective of the research is to ascertain the level of communal noise in comparison to allowable values in specific locations in Sarajevo; and to ascertain whether and to what extent the communal noise in these locations exceeds the allowable values by the Law on noise protection in Sarajevo Canton.

Apart from that, the framework of this paper strives to ascertain the level to which city greenery affects lowering noise levels. 


\section{WORK METHOD - Metod rada}

Noise measuring was performed by using the integrated sound level meter Bruel\&Kjaer 2239 (figure 1). This instrument conforms to IEC 651, 804 and EN 60804 standards. The measuring was performed in the legally prescribed minimum duration of 15 minutes during daytime and night time. The following two most important parameters were measured:

1. Leq $d B(A)$-the average noise energy value of a changeable level equivalent to the noise of a constant level measured for at least 15 minutes

2. MaxP - the highest noise level within the measuring time interval in $\mathrm{dB}$

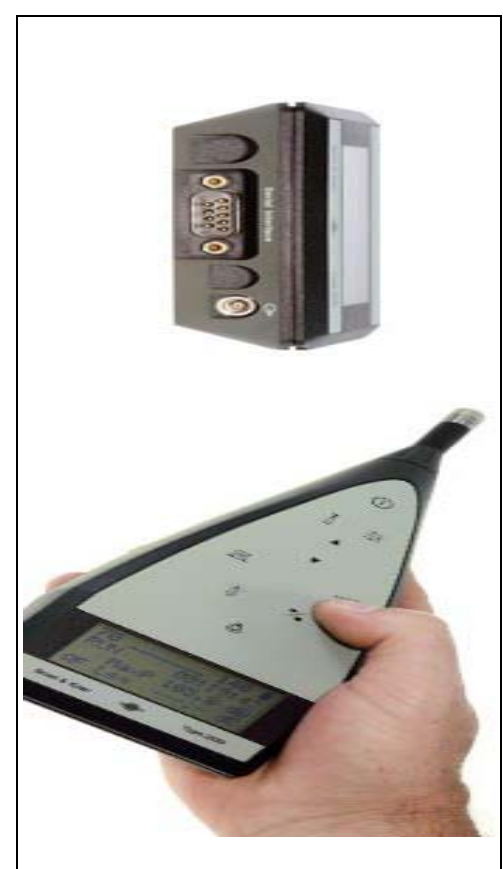

Figure 1. Bruel \& Kjaer 2239

Slika 1. Bruel \& Kjaer 2239

The level of communal noise was measured in two locations in Sarajevo. The first location is the area of the Big Park (figure 2), and the second one is the immediate area around the Faculty of Forestry in Sarajevo (figure 3).

The measuring was performed in open space at an altitude of 1.2 metres. With the aim of minimising the influence of the operator on the microphone, i.e. the registered noise level, the measuring was performed using a corresponding stand. Daytime and night time measuring was performed separately. The measuring was performed in three different positions, i.e. at a different distance from the main city road to the inside of the park $(10,20$ and 30 metres). In the locality 'Faculty of Forestry', the measuring was performed on two sides of the main city road (with and without vegetation). The main objective of such a measuring is to attempt to determine the influence of the present vegetation in the park of the Faculty on the measured communal noise level.

Data processing was performed in a corresponding software (Environmental Software 2.5, and Microsoft Office Excel 2007). 


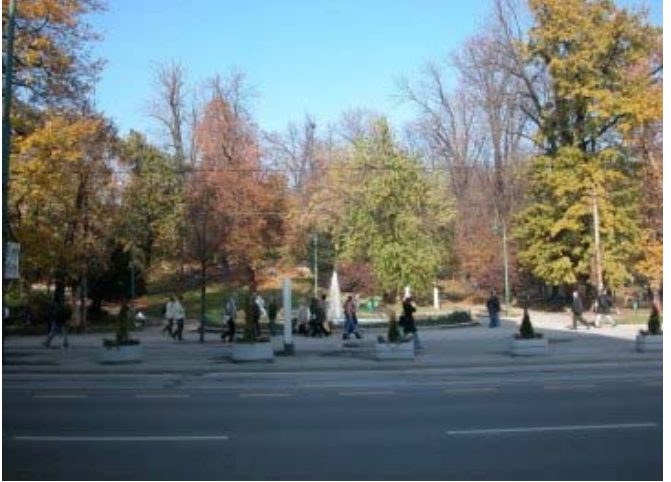

Figure 2. The Big Park

Slika 2. Veliki park



Figure 3. The Forestry Faculty Park

Slika 3. Park Šumarskog fakulteta

\section{RESULTS AND DISCUSSION - Rezultati i diskusija}

\section{Communal noise level in the 'Big Park' locality - Nivo komunalne buke na lokalitetu "Veliki park"}

Measuring communal noise in the locality 'Big Park' was performed from 07. 04. 2011. to 10. 04. 2011., i.e. on three working days. The exact time of individual measurings and the values of the most important communal noise parameters after data processing is presented in figures 4-6.

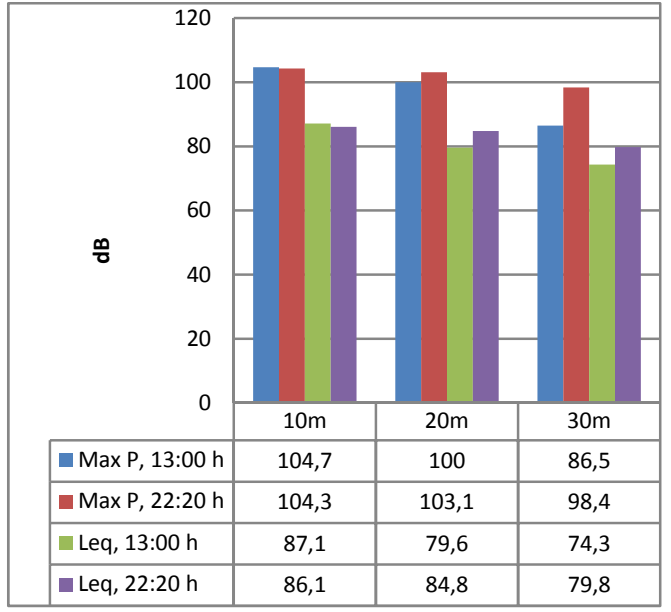

Figure 4. Measured noise levels 07.04.2011. Slika 4. Izmjereni nivoi buke 07.04.2011.

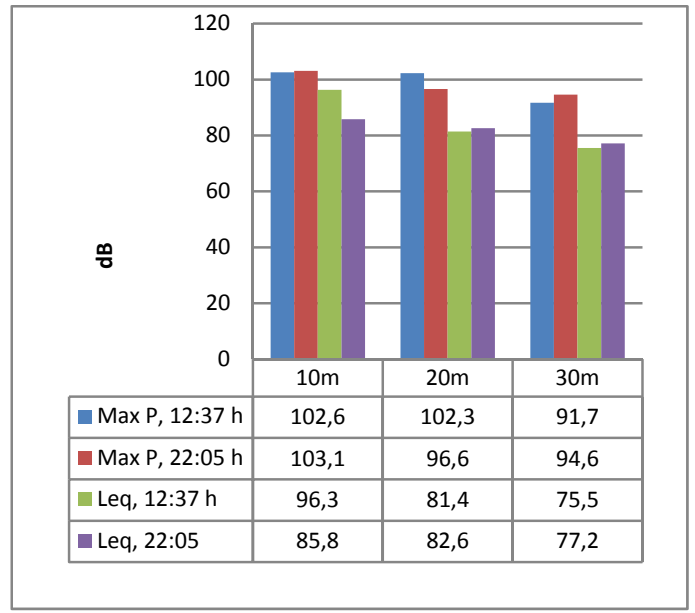

Figure 5. Measured noise levels 08.04.2011. Slika 5. Izmjereni nivoi buke 08.04.2011. 




Figure 6. Measured noise levels 10.04.2011

Slika 6. Izmjereni nivoi buke 10.04.2011

Based on the presented results, it can be said that an exceptionally high level of noise was registered in the locality of the 'Big Park'. There have not been considerable differences between daytime and night time measurings, which is expected, considering the locality chosen and traffic frequency. The greater the distance from the road, the lower the noise levels. Analysis shows that this decrease is more intense during daytime hours (approximately $8.4 \%$ on each 10 metres) as opposed to night time hours (approximately $5.6 \%$ on each 10 metres). The final results greatly correlate to the results presented in the research by SAMARA AND TSITSONI (2007).

In order to gain a clearer idea of the level of registered noise, table 1 presents the levels of the highest allowable noise levels in spaces where people spend their time, depending on the purpose and time spent there, according to the Law on noise protection in Sarajevo Canton. According to this law, daytime is from 06 to 22, and night time is from 22 to 06 o'clock.

Table 1.The highest allowable noise level depending on purpose and time

Tabela 1. Najviši dopušteni nivoi buke u zavisnosti od namjene prostora i vremena

\begin{tabular}{|c|c|c|c|c|c|}
\hline \multirow{4}{*}{$\begin{array}{l}\text { Noise } \\
\text { area }\end{array}$} & \multirow{4}{*}{ Space purpose } & \multicolumn{4}{|c|}{ The highest allowable noise level } \\
\hline & & & $\mathrm{L}_{\mathrm{e}}$ & ) & \\
\hline & & \multicolumn{2}{|c|}{ Outdoor } & \multicolumn{2}{|c|}{ Indoor } \\
\hline & & Day & Night & Day & Night \\
\hline 1. & Recreational & 50 & 40 & 30 & 25 \\
\hline 2. & Residetial & 55 & 40 & 35 & 25 \\
\hline 3. & Mostly residential & 55 & 45 & 35 & 25 \\
\hline 4. & Mostly business & 65 & 50 & 40 & 30 \\
\hline 5. & Economic & \multicolumn{2}{|c|}{ limit $/<80$} & 40 & 30 \\
\hline
\end{tabular}




\section{Communal noise level in the Faculty of Forestry' locality - Nivo komunalne buke na lokalitetu "Šumarski fakultet"}

The measuring of noise levels in this locality was performed on 26. and 27.04.2011. (two days) and those are only daytime measurings. The same basic noise parameters were measured, and the final results are presented in figure 7.

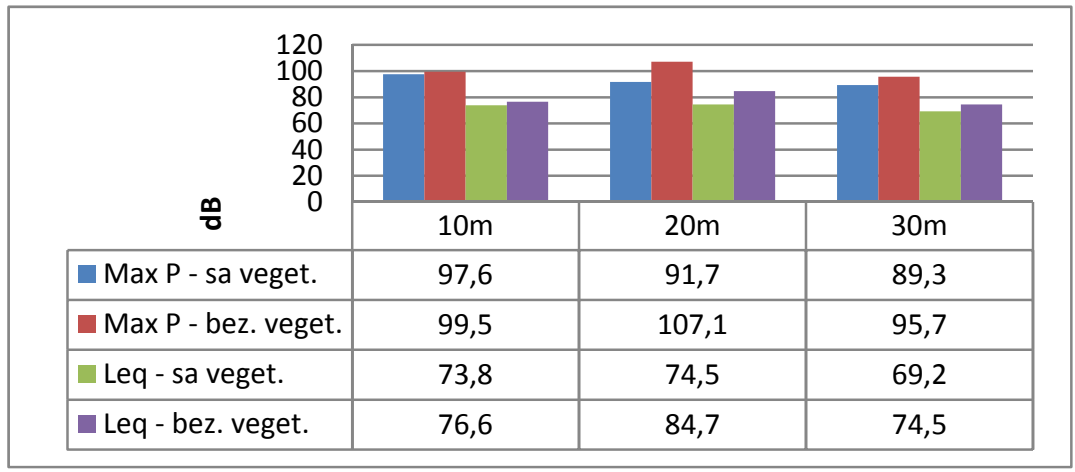

Figure 7. Measured average daily noise levels

Slika 7. Izmjereni prosječni dnevni nivoi buke

Significantly lower noise levels are registered in this locality as opposed to the 'Big Park' locality. Leq is on average lower for around $12 \%$. The main reason for these results is certainly the position of this locality (the city centre, city traffic, tramcar noise, etc.). The influence of the Forestry Faculty park vegetation (trees and shrubs) on the decrease of communal noise is evident. The highest level of registered noise is lower on average by $8 \%$, and the average energy value (Leq) is lower by $7.7 \%$ in the area with vegetation as opposed to the barren area. Although the measurings were performed before leaves sprouting, the vegetation present considerably influenced the decrease of noise levels, and this influence would be more evident in summer months.

\section{CONCLUSIONS - Zaključci}

Based on the presented and discussed results of the research, the following most important conclusions can be drawn:

- $\quad$ Noise levels in the analysed localities in Sarajevo greatly exceed the allowable values regulated by the Law on noise protection and recovery measures are needed.

- The noise levels are reduced the further away you are from the main city road, and this decrease is more evident during daytime hours. The final results correlate with results of similar research to a great extent. 
- Although the measurings were performed before leaves sprouting, city greenery considerably lowered the noise levels. It is assumed that this influence would be more evident during summer months.

- In order for green spaces to be more efficient in noise protecting functions, it is necessary, when planning green spaces, to pay attention to the selection of tree types and shrubs, and plant the ones which absorb acoustic pollution well.

\section{REFERENCES - Literatura}

BOGADI-ŠARE, A. (2005): Uloga medicine rada u zaštiti zdravlja od djelovanja buke. Knjiga sažetaka simpozija „Buka i zdravlje“, Zagreb 08. Prosinca 2005.

CODER, D.R. (1996): Identified Benefits of Community Trees and Forests. University of Georgia Cooperative Extension Service - Forest Resources Publication FOR 96-39.

DIRECTIVE 2002/49/EC of the European Parliament and of the Council.Official Journal of the European Communities.

EuRopean Commission (1996): Green Paper on Future Noise Policy, COM (96) 540.

EuRopean Commission (2001): Environment 2010: Our Future, Our Choice, 6th EU Environment Action Programme.

Gomzı, M. (2005): Svakodnevna buka i moguće zdravstvene posljedice. Knjiga sažetaka simpozija „Buka i zdravlje“, Zagreb 08. Prosinca 2005.

GREGUREK, R. (2005): Buka i psihološko zdravlje. Knjiga sažetaka simpozija „Buka i zdravlje“, Zagreb 08. Prosinca 2005

Niemann, H., Masche, C. (2004): WHO LARES - Final report Noise effects and morbidity. World Health Organization.

NiJlAND, H., WEE, V.B. (2008): Noise valuation in ex-ante evaluations of major road and railroad projects. EJTIR, Issue 8 (3), pp. 216-226.

SAMARA, TH., TSITSONI, T. (2007): Road traffic noise reduction by vegetation in the ring road of a big city. Proceedings of the International Conference on Environmental Management, Engineering, Planning and Economics, Skiathos June 24-28, 2007, Pages: 2591-2596

VuJković LJ. (2003): Pejsažna arhitektura - planiranje i projektovanje. "Lion" Beograd.

VIDAKOVIĆ, Z. (2012): Monitoring buke u životnoj sredini na teritoriji grada Subotice u toku 2011. godine. Zavod za javno zdravlje Subotica, godišnji izvještaj.

Zakon o zaštiti od buke Kantona Sarajevo. Službene novine Kantona Sarajevo, br. 26/07. 


\section{SAŽETAK}

Pod bukom se podrazumijeva neželjen, odnosno preglasan, neugodan ili neočekivan zvuk koji se negativno odražava na fizičko i/ili psihičko zdravlje ljudi. Buka ometa odvijanje ljudskih aktivnosti, izaziva neraspoloženje, razdražljivost, nemir, smetnje mentalnog zdravlja i ponašanja, umor i nesanicu, a kod razine buke iznad $80 \mathrm{~dB}$ javlja se i agresivno ponašanje. Buka u urbanim sredinama, a to znači svuda gdje čovjek živi i radi, kojoj su ljudi svakodnevno izloženi naziva se okolinska, komunalna ili opća buka. Komunalna buka predstavlja veliki problem užeg ljudskog okoliša, posebno u urbanim sredinama. Jedno od pouzdanih sredstava zaštite od komunalne buke su različite vrste zelenih zasada. Oni djeluju tako što upijaju zvučne talase i na taj način smanjuju nivo buke. Stepen zaštite od buke utoliko je veći ukoliko je veća gustina i dubina zasada, a efektivnost njenog smanjenja zavisi i od karaktera zasada (sastava, rasporeda biljaka, konstrukcije, gustine, prisustva podrasta i sprata žbunja, visine i dr.).

U vezi sa navedenim, u okviru ovog rada obavljena su mjerenja razine komunalne buke na dvije karakteristične lokacije u gradu Sarajevu. Osnovni cilj ovih mjerenja je da se, u komparaciji sa dopuštenim vrijednostima (Zakon o zaštiti od buke Kantona Sarajevo), utvrdi da li i u kojoj mjeri komunalna buka premašuje zakonski propisani nivo. Pored toga, u okviru rada nastojalo se utvrditi u kojoj mjeri gradsko zelenilo utiče na smanjenje nivoa buke.

Rezultati rada pokazali su da izmjereni nivoi buke na oba lokaliteta u velikoj mjeri premašuju dozvoljene vrijednosti propisane pomenutim zakonom. Utvrđeno je također da gradsko zelenilo smanjuje nivo buke za oko $8 \%$, te su u radu date preporuke o načinu podizanja zelenih gradskih površina u funkciji zaštite od buke. 